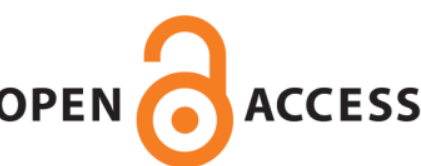

UWS Academic Portal

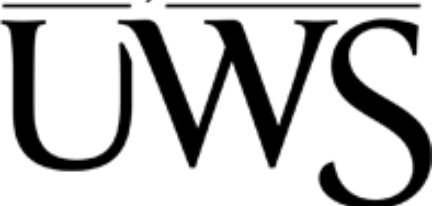

\title{
What does Brexit tell us about our understanding of European identity?
}

Leith, Murray; Sim, Duncan; Van Der Zwet, Arno; Boyle, Elizabeth

Published in:

Political Quarterly

DOI:

10.1111/1467-923X.12734

Published: 13/08/2019

Document Version

Peer reviewed version

Link to publication on the UWS Academic Portal

Citation for published version (APA):

Leith, M., Sim, D., Van Der Zwet, A., \& Boyle, E. (2019). What does Brexit tell us about our understanding of European identity? Political Quarterly, 90(3), 559-564. https://doi.org/10.1111/1467-923X.12734

\section{General rights}

Copyright and moral rights for the publications made accessible in the UWS Academic Portal are retained by the authors and/or other copyright owners and it is a condition of accessing publications that users recognise and abide by the legal requirements associated with these rights.

Take down policy

If you believe that this document breaches copyright please contact pure@uws.ac.uk providing details, and we will remove access to the work immediately and investigate your claim. 
"This is the peer reviewed version of the following article: Leith, M., Sim, D., Van Der Zwet, A., \& Boyle, E. (2019). What does Brexit tell us about our understanding of European Identity? POLITICAL QUARTERLY, which has been published in final form at https:// doi.org/10.1111/1467-923X.12734. This article may be used for non-commercial purposes in accordance with Wiley Terms and Conditions for Use of Self-Archived Versions."

https://authorservices.wiley.com/author-resources/Journal-Authors/licensing/self-archiving.html 


\title{
WHAT DOES BREXIT TELL US ABOUT OUR UNDERSTANDING OF EUROPEAN IDENTITY?
}

\author{
Murray Stewart Leith, Duncan Sim, Arno van der Zwet, and Elizabeth Boyle
}

\begin{abstract}
This paper reports on a number of Eurobarometer surveys undertaken by the European Commission as a way of reflecting on Brexit and the challenges it poses to European identity. Our work with the surveys has been undertaken in the context of developing an educational game (RU EU?) which will explore European identity. European citizenship and identity have been strongly promoted by the EU but, while they appear to have been accepted at an elite level, the EU - and the UK in particular - have so far not constructed a narrative which has been supported by 'ordinary' citizens. Brexit has therefore exposed the failings of European elites in this regard. That said, there is some evidence that the complexities of Brexit have led to a strengthening of European identity in the other EU 27 countries.
\end{abstract}

\section{Keywords}

Brexit, European Union, European identity, educational gaming

\section{Introduction}

Brexit has dominated UK politics for at least the last three years and it is not the intention of this paper to revisit the referendum or to analyse the vote itself. However, what was clear during the referendum campaign and remains the case is an apparent lack of knowledge about the EU, its institutions and its workings. Eurobarometer surveys show the UK as having the highest 'knowledge deficit' about the EU across the union, and this has perhaps allowed UK political elites to 'blame' Europe for various ills, unchallenged. Euroscepticism has entered the political mainstream, and leading Conservative Party figures have taken that message into the heart of Government.

The rise of populism elsewhere in Europe suggests that the European project is being challenged as never before and both the European and wider global political climates, indicate that we may well be re-entering a political era driven by national rather than international imperatives. The issues of nationalism and national identity therefore require not only attention, but better understanding.

In this paper, we use various findings from the EU's Eurobarometer surveys to reflect on Brexit and the UK's relationship with the EU, our work carried out in the context of setting up an educational game project, entitled RU EU?. This project aims to create an educational platform that will allow students and other players across Europe to develop a clearer understanding, not only of their own national and European identities and values, but also those of others. The development of the game itself is described elsewhere ${ }^{i}$ but the project has involved an exploration of European identity 
issues and, given that our work has been conducted in the shadow of Brexit, we believe that Brexit can tell us much about our understanding of European identity.

What, for example, can we say about the relationship between British and European identity? If Britons are Eurosceptic, but at elite level there is support for European integration, then is European identity an exclusive one which has not engaged 'ordinary' citizens? While some aspects of a European identity (such as the common currency) may be viewed with suspicion within the UK, are there other aspects of being European, such as rights and protections, which are viewed more positively? We begin by looking briefly at the historical relationship between the UK and the EU before exploring European identity in greater detail.

\section{The UK and the EU: the historical relationship}

The UK has always appeared to have difficulty in 'feeling European'. It was invited to join, first the European Coal and Steel Community and later the European Economic Community (EEC) in 1957, but declined and while many politicians like Churchill supported post-war European integration, they did not necessarily see Britain as being part of it. This ambivalent attitude allowed the American Secretary of State Dean Acheson to make his famous remark that Britain had 'lost an Empire but not yet found a role'.

But, by the early 1960s, economic growth in the EEC had begun to outstrip that in the UK. The UK joined in 1973 but appeared to be an 'awkward partner' and the British elite continued to celebrate their distinctiveness as opposed to Europeanness; Europe was 'rarely constructed as a political community of fate in the British political discourse'ii and European and British identities were often viewed as incompatible.

Meanwhile, elsewhere in the EU, the formal decision to develop and promote a European identity was taken in Copenhagen in December 1973, recognising that it was increasingly difficult for any one nation to act alone. The idea of a European identity was based on the unity of the then nine member states, and their collective responsibilities towards other European countries, the USA, the Middle East, Africa and Asia. The ensuing Tindemans Report (1975) recommended a 'People's Europe' and in 1983, the member states agreed, in Stuttgart, to promote 'European awareness and to undertake joint action in various cultural areas'. Thus a European identity was developed as a mix of political and cultural ambitions.

In 1991, the Maastricht Treaty introduced the concept of European citizenship, such that the core elements of citizenship, rights and identity, are not 'attached' to citizens as members of separate EU member states, but to citizens as citizens of the EU itself, perceived as a democratic political union - an uncoupling of 'ethnos' and 'demos'. Thus the EU shifted from a project of economic integration to one which also embraces political and cultural integration. This has created a concern for the UK as such integration begins to transcend national identity and cultural allegiances

\section{The components of a European identity}


There are different ways of belonging to Europe and the EU has increasingly become normalised within the lives of its citizens. But, perhaps because there is no clear agreement on what a European identity actually is, there appears to be a growing consensus - at least within elites - that it is about cosmopolitanism and diversity. Thus Delantyiii suggests that one of the features of European history has been the constant negotiation of difference, leading to a more cosmopolitan culture 'the ability to see the other within the self and oneself as other'. It means 'the recognition of living in a world of diversity and a belief in the fundamental virtue of embracing positively the values of the other. While this was once an identity of the European elites, there is some evidence that it has become a more general identity for all Europeans'. European identity has also been characterised as 'unity in diversity', a term first used by Nehru to define the national identity of India. Thus 'cosmopolitanism' or 'unity in diversity' are terms which describe a Europe-wide identity, although this may be challenged by Brexit. Indeed, there are many (not just in the UK) who may see these as elite constructions which are actually exclusive.

In a European context, nations emerged from communities that had an ethnic, linguistic or cultural cohesion but the French Revolution introduced the concept of a nation based on citizenship, and modern European identity is often seen in these terms - as a coming together voluntarily of nation states, leading to a shared political system and a common citizenship. A European citizenship therefore has a strong civic component in terms of shared political rights but lacks a significant ethnic dimension that defines itself against others ${ }^{\text {iv }}$.

Indeed, research indicates that Europeans orientate themselves particularly towards civic aspects of their European identity, associating it with their EU citizenship, their political structures and their rights. Cultural identifiers - peace, harmony, cooperation and the fading of historical divisions - are less significant. UK citizens, however, have tended to view European identity as ethnic and therefore a challenge to national British identity. The lack of engagement with a civic European identity may reflect the UK's remaining outside the Eurozone and the Schengen area, both of which may contribute to a wider civic sense of European-ness.

\section{Who feels European?}

Given the active promotion of a European identity, then has it actually made more of us 'feel' European? The Eurobarometer surveys are useful in this regardv Essentially, educational attainment shows the strongest relationship to a feeling of European identity, with educated individuals generally considering themselves to be European while those who left school early rarely do so. The second most influential variable is income, as those with higher incomes will travel more and participate in European life. Generational criteria are also important; a minority (46\%) of respondents born before 1946 define themselves as European, whereas after 1946, the figure rises to over $60 \%$. Older people may be less adventurous, less likely to know other languages and are influenced by wartime experiences. Being European is therefore bound up with who you are, how you live and how you were brought up. There is also a correlation with having cosmopolitan attitudes, positive attitudes to immigrants and being politically left of centre. The 'non-Europeans' or those who 
hold to an exclusive national identity are those with an opposite background and beliefs.

This summary of 'non-Europeans' would seem to mirror the UK's Brexit vote, where there was a strong correlation with age and educational attainment. A majority of those aged 45 and over voted to Leave, while a majority of those under 45 voted to Remain. In a nutshell, "the "winners" of globalization - the young, well-educated professionals in urban centres - favour more open borders, immigration and international co-operation'vi. The result in the referendum was that those with fewer educational qualifications tended to vote to Leave.

It is clear, therefore, that there are significant differences between the views of the younger educated European elites and the views of 'ordinary' citizens. The Eurobarometer surveys suggest $84 \%$ of upper middle class Europeans see themselves as European citizens compared with only $44 \%$ of working class people, although the terminology used is rather imprecise; the figures may reflect the extent to which Europe impacts on most people's daily lives. Even where EU policies do impinge on the lives of citizens, this may be filtered by national governments and other interested parties, making it difficult for many to understand the extent to which they are winners or losers in the EU context. Perhaps, therefore, one of the greatest failings of elites has been in formulating an identity in which the less well-off can find themselves and to inculcate such an identity in 'non-Europeans'. Had this occurred, some 'ordinary' citizens in the UK might have voted differently.

\section{National versus European identity}

One of the major themes which ran through the Brexit campaign was the relationship between European and national identities, specifically a suggestion that a European identity had somehow begun to extinguish a British (or more specifically English one). In fact, for many EU citizens, their identities are nested, with their national identity contained within a wider European one. For others, their identities are more intertwined, a model which is sometimes referred to as resembling a marble cake ${ }^{\mathrm{vii}}$.

Because Europe lacks many of the core components of a national identity - a shared language, religion, educational system and media - a European identity is something else, a civic identification with democracy, rights and constitutional norms rather than the nation and its cultural traditions. Because national and European identities are somewhat different, therefore, they can co-exist and are not necessarily in conflict with each other. Indeed, all national identities contain, to some extent, a European element; globalisation has impacted on all nations and national identities are not closed to these global and cosmopolitan influences.

But, if this is the case, how can we explain the relationship between national and European identity in the context of the UK? Many member states have seen the EU as providing some sort of solution to their own individual circumstances. Germany's desire for a more integrated Europe reflects the post-war reconstruction of its national identity. French identity was challenged partly by post-war reconstruction but also by decolonialisation (especially in Algeria) while many Italians have seen the EU as a more stable political structure than Italy itself. For Spain, EU membership 
was part of a post-Franco modernisation programme, while for eastern Europe, joining the EU was an important step after the end of the Cold War. The UK, however, seems to have failed to construct the EU after its own individual circumstances and has not created a narrative, supportive of the $E U$, to which all citizens could subscribe.

There is of course no 'one size fits all' European identity. But, although European identity is sometimes challenged, the vast majority of those who fear the loss of national identity as a result of European integration did not think their country's membership of the EU was itself a bad thing. The key seems to lie in the notion of exclusive national identity. Eurobarometer data reveal that there are those who hold to their national identity to the exclusion of a European one, thinking of themselves as only British or French or whatever. The country with the greatest level of exclusive national identity is the UKviii.

This analysis simply confirms the lukewarm attitude of many UK citizens towards the EU. Risse ${ }^{i x}$ believes that the:

'prevailing English nation-state identity still perceives Europe as the (friendly) "other". The distinctive nationalist English identity is incompatible with federalist or supranationalist visions of European political order. It explains why British governments, whether Conservative or Labour, have consistently been reluctant to support a deepening of European integration'.

In the UK in particular therefore, European identity is seen as being in conflict with national identity rather than being complementary to it and British Euroscepticism has a long history. According to Miall ${ }^{\mathrm{x}}$, 'English views on foreigners are very simple. The further one travels from the capital in any direction, the more outlandish the people become'. Thus for the UK (and particularly England), Europe itself is the 'other' and this was reflected in the Brexit vote.

\section{Discussion: Brexit and the future for a European identity}

What then can Brexit tell us about our understanding of European identity in the longer term? One of the ironies inherent in Brexit is the fact that the UK itself played a major role in shaping the EU's liberal economic agenda and, although Margaret Thatcher is remembered as being hostile to Europe, she signed the Single European Act as she thought it would serve British interests by spreading liberalisation. The UK was also an early advocate of EU enlargement and the extension of membership to east European countries. But, although the UK was successful in shaping the EU in terms of neoliberalism, even Europhile politicians failed to construct a supporting narrative at home.

A key concern in the Brexit referendum was immigration although, again ironically, the roots of the UK's raised levels of immigration lie in the decision taken by the Blair government in 2004 to allow workers from the new accession countries in eastern Europe free entry to work in the UK; only Ireland and Sweden allowed similar access. Even though this benefited the UK economy and therefore the UK could have constructed the EU to its benefit, the narrative has failed domestically. 
Elsewhere in the EU, the arrival of large numbers of refugees from 2015 onwards precipitated a crisis in the Schengen agreement. Many arrived by sea into Greece and Italy and, once accepted as refugees, should have had the right to free movement across the EU. This did not happen and a number of countries instigated border controls, in defiance of Schengen rules. Many refugees are Muslim and rightwing politicians have sought to place Islam as 'the other', somehow threatening a 'Christian' Europe.

In the UK, by contrast, it is the EU itself that has become 'the other' and the 'whipping boy' of right-wing UK politicians and media. Speeches by politicians often refer to 'Britain and Europe' as if they were opposing concepts and that, somehow, the UK was not a European country. The discourse is frequently one of distinction and, as Spiering ${ }^{\mathrm{xi}}$ points out, 'Britain is not so much partaking in European integration, but integrating (or attempting to integrate) with an outside entity called "Europe"'.

While political scepticism is healthy in a democracy, there is perhaps a responsibility on political elites to promote a balanced view so that citizens can form a considered opinion. Indeed, elites can play a significant role through the adoption of pro- or antiEuropean messages and platforms. But the rise of far-right populist parties in Europe suggests that European elites have failed to convince many (particularly working class) voters that the EU is an organisation which benefits them.

At the time of writing, Brexit is imminent. But it is not at all clear that it has dealt a blow to European identity or to further integration and there has been considerable ongoing debate about European identity and the European project - a key reason for the development of the RU EU? game, to enable students and other game players to explore the issue more widely. The 2018 Eurobarometer surveys shows that support for EU membership is actually at its highest since the surveys began in 2007. Perhaps the complications and realities of the Brexit negotiations have persuaded the other 27 member states that they are better off staying where they are - and indeed the 2019 survey reports that $61 \%$ of EU citizens agree that it is better to be inside than outside the EU. Many right-wing parties have been successful in recent years, but would not necessarily support their country leaving the EU entirely. In any case, in the recent European elections, a big populist Eurosceptic surge failed to happen and, although the centrist parties lost ground, the radical Greens were among the biggest winners.

In some respects, the Brexit vote is not really about the EU at all but represents what Calhoun ${ }^{x i i}$ calls a 'mutiny against the cosmopolitan elite'. Elites may have accepted the European project and European identity but ordinary people, particularly in the UK, have not been convinced. The EU may be bureaucratic and cumbersome but it has defended human rights and addressed environmental issues including climate change. The rise of the populist right suggests there are significant challenges to EU integration, and political elites need to do much more to convince 'ordinary' citizens that the EU is working for them. But recent surveys seem to indicate that, while Brexit may be regrettable, it will not in the longer term, derail the development of a stronger European identity and may well have the opposite effect. 


\section{Funding}

This work reported in this paper was carried out as part of the RU EU? A gamebased approach to exploring 21st century European identity and values project. This project is partially supported by a KA203 Erasmus+ Strategic Partnerships for Higher Education grant (Grant Agreement no: 2017-1-UK01-KA203-036601) and is a collaboration between the University of the West of Scotland, the Open University of the Netherlands, Tehničko veleučilište $u$ Zagrebu (Croatia), the University of Peloponnese (Greece) and Bremer Institut für Produktion und Logistik Gmbh (Germany).

\section{Author biographies}

Dr Murray Stewart Leith is Reader in Politics at the University of the West of Scotland.

Dr Duncan Sim is Honorary Senior Research Fellow (and formerly Reader in Sociology) at the University of the West of Scotland.

Dr Arno van der Zwet is a Lecturer in Politics and Public Policy at the University of the West of Scotland and a senior research associate at the European Policies Research Centre at the University of Strathclyde.

Dr Elizabeth Boyle is Reader in Psychology at the University of the West of Scotland.

'Leith, M., Boyle, L., Sim, D., van der Zwet, A., Scott, G., Jimoyiannis, A., Jandrić, P., Hauge, J. B., Tany, N. S. and Hummel, H. (2019), 'What's in a game? A game-based approach to exploring 21st century European identity and values', Open Review of Educational Research, 6.1, pp.12-25.

ii Risse T (2003) The Euro: between national and European identity. Journal of European Public Policy 10 (4): 487-505

iii Delanty G (2002) Models of European identity: reconciling universalism and particularism. Perspectives on European Politics and Society 3 (3): 345-359; Delanty G (2003) Is there a European identity? Global Dialogue 5 (3/4): 76-86; and Delanty G (2005), What does it mean to be a European? Innovation: The European Journal of Social Science Research 18 (1): 11-22

iv Mendez C and Bachtler J (2016) European identity and citizen attitudes to cohesion policy: what do we know? Glasgow: Cohesify Research Paper 1; Cram L (2012) Does the EU need a navel? Implicit and explicit identification with the European Union. Journal of Common Market Studies 50 (1): 71-86 
$\checkmark$ See, for example, European Commission (2015) European citizenship. Standard Eurobarometer 83, Brussels: EC, and Eurobarometer 88 (2017)

vi Hobolt SB (2016) The Brexit vote: a divided nation, a divided continent. Journal of European Public Policy 23 (9): 1259-1277

vii Risse T (2003), Op cit.

viii Marks G and Hooghe L (2003) National identity and support for European integration, Berlin:

https://www.ssoar.info/ssoar/bitstream/handle/document/11155/ssoar-2003marks et al-national identity and support for.pdf?sequence=1; and McLaren L (2004) Opposition to European integration and fear of loss of national identity: debunking a basic assumption regarding hostility to the integration project. European Journal of Political Research 43: 895-911

${ }^{i x}$ Risse T (2001) A European identity? Europeanization and the evolution of nationstate identities. In Cowles MG, Caporaso J and Risse T (eds) Transforming Europe. Ithaca: Cornell University Press, pp.198-216

× Miall A (1993) The xenophobe's guide to the English. London: Ravette Books

xi Spiering M (2015) A cultural history of British Euroscepticism. Basingstoke:

Palgrave Macmillan

xii Calhoun C (2017) Populism, nationalism and Brexit. In Outhwaite W (ed) Brexit: sociological responses. London: Anthem Press, pp.56-76 